JURNAL ASTA

Abdi Masyarakat Kita

Vol. 02 No. 01, Januari 2022

\title{
Edukasi Pentingnya Asi Eksklusif Pada 1000 Hari Pertama Kehidupan Anak
}

Intan Sari ${ }^{1}$

${ }^{1}$ AKBID Budi Mulia Prabumulih

E-mail:intanbudimulia@gmail.com

Ana Sapitri

${ }^{2}$ AKBID Budi Mulia Prabumulih

E-mail:anasapitri6@gmail.com

\author{
Maria Septiana ${ }^{3}$ \\ ${ }^{3}$ AKBID Budi Mulia Prabumulih \\ E-mail :septianamaria608@gmail.com
}

Article History:

Received: 2021-09-23

Revised: 2021-12-30

Accepted: 2022-01-25
Abstract: From an early age children's growth and development requires attention to get a great opportunity so that the growth and development process can take place properly. Parents need to get knowledge about the golden age period and what needs to be prepared in dealing with this period, so that in order to reduce child morbidity and mortality, the United Nations Children's Fund (UNICEF) and the World Health Organization (WHO) strongly recommend that children should only be given water. Mother's milk (ASI) for at least six months. Solid food should be given after the child is 6 months old, and breastfeeding is continued until the child is two years old. The purpose of this activity is to educate parents, especially mothers, to give exclusive breastfeeding to their children, especially in the work area of the Sukajadi Public Health Center, Prabumulih City. . The method used in this activity is lectures, discussions and training on breastfeeding activities correctly, this community service activity was carried out at the Sukajadi Health Center, Prabumulih City from November 01st-06th, 2021, it went smoothly and got a good response 
JURNAL ASTA

Abdi Masyarakat Kita

Vol. 02 No. 01, Januari 2022

Keywords: Golden age, Ezclusive

breastfeeding, Baby and enthusiastic community. Each participant is given a message about the importance of exclusive breastfeedin

\section{Riwayat Artikel :}

Diajukan: 23-09-2021

Diperbaiki: 30-12-2021

Diterima: 25-01-2022
Kata kunci : Periode emas, ASI Eksklusif, Bayi

\begin{abstract}
Abstrak: Sejak dini pertumbuhan dan perkembangan anak membutuhkan perhatian untuk mendapatkan kesempatan yang besar agar proses tumbuh dan berkembang dapat berlangsung dengan baik, Periode golden age merupakan tahapan pertumbuhan dan perkembangan anak dimana pada periode ini otak dan fisik mengalami pertumbuhan optimal. Orang tua perlu mendapatkan pengetahuan mengenai periode golden age dan apa saja yang perlu dipersiapkan dalam menghadapi masa tersebut. Dalam rangka menurunkan angka morbiditas dan mortalitas anak United Nation Childrens Fund (UNICEF) dan World Health Organization(WHO) sangat menyarankan sebaiknya anak hanya diberikan Air Susu Ibu (ASI) selama paling sedikit enam bulan. Makanan padat seharusnya diberikan sesudah anak berumur 6 bulan, dan pemberian ASI dilanjutkan sampai anak berumur dua tahun, Tujuan dari kegiatan ini adalah untuk mengedukasi para orang tua terutama ibu untuk memberikan Asi secara Ekslusif kepada anak nya khusus nya di wilayah kerja Puskesmas Sukajadi Kota Prabumulih. Metode yang digunakan dalam kegiatan ini adalah ceramah, diskusi dan Pelatihan kegiatan menyusui secara benar. Kegiatan pengabdian masyarakat ini di lakukan di Puskesmas Sukajadi Kota Prabumulih pada tanggal 01 November 2021 hingga 06 November 2021 berjalan lancar dan mendapatkan respon yang baik serta antusias masyarakat. Setiap Peserta diberikan selembaran mengenai pentingnya ASI Eksklusif.
\end{abstract}




\section{Pendahuluan}

Pemberian ASI secara Eksklusif merupakan bayi hanya diberi ASI Saja tanpa tambahan caiaran lain seperti susu formula, jerukm madu, ait teh, air putih dan tanpa tambahan makanan padat seperti pisang, pepaya, bubur susu, biskuit, bubur nasi dan tim, (Roesli, 2000). ASI (Air Susu Ibu) merupakan nutrisi yang tepat untuk bayi yang mengandung unsur zat gizi penting untuk memenuhi kebutuhan bayi dan terdiri dari zat antibodi yang baik untuk meningkatkan sistem kekebalan tubuh bayi. Tiga tahun pertama kehidupan seorang anak sangat penting karena nutrisi yang optimal selama periode ini menurunkan angkat mobiditas serta mortilitas, mendorong perkembangan yang lebih baik dan mengurangi resiko penyakit kronis. Kekurangan gizi yang dialami bayi dan anak akan menimbulkan dampak gangguan pertumbuhan dan perkembangan jika tidak bisa diatasi dengan baik dan dapat berlangsung hingga anak dewasa nantinya. (Lestari, 2014)

Dalam rangka menurunkan angka morbiditas dan mortalitas anak, United Nation Childrens Fund (UNICEF) dan World Health Organization(WHO) merekomendasikan sebaiknya anak hanya diberikan Air Susu Ibu (ASI) selama paling sedikit enam bulan. Makanan padat seharusnya diberikan sesudah anak berumur 6 bulan, dan pemberian ASI dilanjutkan sampai anak berumur dua tahun (WHO, 2005). Pada tahun 2003, pemerintah Indonesia mengubah rekomendasi lamanya pemerian ASI Eksklusif dari 4 bulan menjadi 6 bulan. (Pusdatin, 2014).

Sejak dini pertumbuhan dan perkembangan anak membutuhkan perhatian untuk mendapatkan kesempatan yang besar agar proses tumbuh dan berkembang dapat berlangsung dengan baik. Periode golden age merupakan tahapan pertumbuhan dan perkembangan anak dimana pada periode ini otak dan fisik mengalami pertumbuhan optimal. Orang tua perlu mendapatkan pengetahuan mengenai periode golden age dan apa saja yang perlu dipersiapkan dalam menghadapi masa tersebut.(Satria, 2021).

Beberapa penelitian epidemiologis menyatakan bahwa ASI melingdungi bayi dan anak dari penyakit infeksi, misalnya diare, otitis media, dan infeksi saluran pernafasan akut bagian bawah. (Pusdatin, 2014). Berdasarkan penelitian dari Tetti Serianti dan Riska Susanti. 2019 yang menyatakan bahwa edukasi berbasis keluarga mampu meningkatkan 
pengetahuan ibu hamil tentang IMD dari 8 orang (40\%) dengan tingkat pengetahuan baik menjadi 17 orang (85\%), terjadi peningkatan sebesar $45 \%$.

Berdasarkan latar belakang diatas, para penulis tertarik untuk melakukan pengabdian masyarakat berupa Edukasi Pentingnya ASI Ekslusif pada 1000 Hari Kehidupan anak di Wilayah Kerja Puskesmas Sukajadi Prabumulih Sumatera Selatan.

\section{Metode}

Kegiatan pengabdian pada masyarakat ini dilaksanakan selama 1 Minggu pada tanggal 1 November hingga 6 November 2021 di Wilayah kerja Puskesmas Sukajadi Prabumulih . Kegiatan dimulai dari pukul 09.00 WIB sampai dengan 12.00 WIB. Adapun peserta pada pengabdian masyarakat ini adalah masyarakat dari kelurahan Sukajadi dan peserta berjumlah sebanyak 30 orang merupakan perwakilan dari 6 RT terdiri dari 5 orang. Sedangkan tim dosen yang terlibat sebanyak 3 orang. Pengabdian masyarakat dilaksanakan dengan dengan metode ceramah, diskusi serta tanya jawab.

Kegiatan diawali dengan pemaparan materi oleh Dosen Akbid Budi Mulia Prabumulih. Adapun materi yang disampaikan antara lain pengertian ASI Eksklusif, Manfaat ASI bagi Bayi dan Ibu, Tehnik dan Tips Sukses Menyusui, Cara penyimpanan ASI, Pengertian Periode Golden Age, Dampak yang terjadi apabila gagal melewati periode Golden Age. Setelah peserta mendapatkan materi, kemudian peserta melakukan praktek tehnik menyusui yang benar dilakukan oleh peserta perempuan dibimbing langsung oleh para dosen, diakhir penyuluhan

dilakukan evaluasi berupa tanya jawab terhadap peserta kegiatan.

\section{Hasil dan Diskusi}

Kegiatan ini dilaksanakan bekerjasama dengan Puskesmas Sukajadi Prabumulih dan melibatkan Dosen Akbid Budi Mulia Prabumulih sebagai narasumber. Sebelum kegiatan berlangsung, seluruh peserta, panitia dan narasumber diwajibkan mentaati protokol kesehetan seperti mengukur suhu tubuh, mencuci tangan dan selama kegiatan berlangsung menggunakan masker atau shield face (pelindung wajah).

Beberapa peserta merupakan remaja putri, ibu hamil, Ibu menyusui dan laki-laki. 
JURNAL ASTA

Abdi Masyarakat Kita

Vol. 02 No. 01, Januari 2022

Kegiatan ini merupakan salah satu kegiatan pengabdian masyarakat oleh LPPM Akbid Budi Mulia Prabumulih. Pembukaan kegiatan dihadiri oleh Pimpinan Puskesmas Sukajadi Prabumulih, Kepala Kelurahan Sukajadi, Para Bidan, tenaga kesehatan lainnya dan beberapa kader kesehatan Kelurahan Sukajadi. Maksud dari kegiatan ini adalah memberikan edukasi kepada masyarakat khususnya yang ada di Kelurahan Sukajadi Prabumulih tentang pentingnya pemberian ASI Eksklusif pada 1000 Hari Pertama Kehidupan.

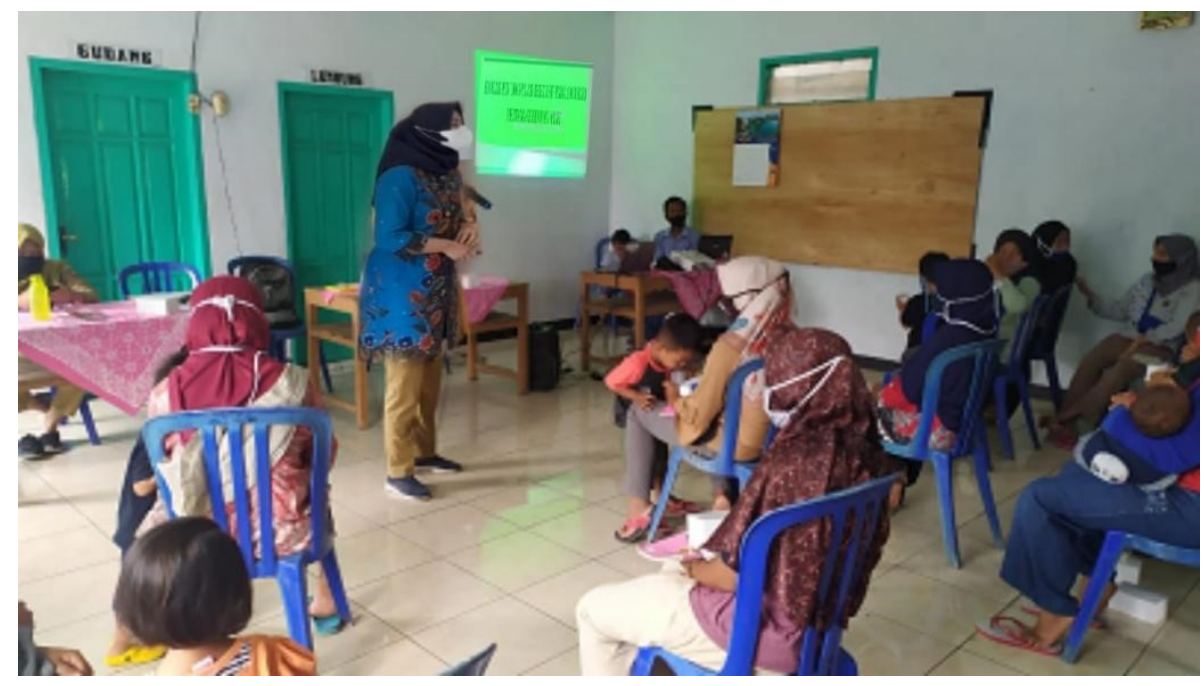

Gambar 1. Dosen sedang memberikan Edukasi mengenai ASI Ekslusif

Peserta terlebih dahulu mendapatkan pemaparan materi antara lain tentang (1) pengertian ASI Eksklusif, (2) Manfaat ASI bagi Bayi dan Ibu, (3) Tehnik dan Tips Sukses Menyusui, (4) Cara penyimpanan ASI, (5) Pengertian Periode Golden Age, (5)Dampak yang terjadi apabila gagal melewati periode Golden Age. Setelah mendapatkan materi, peserta mempraktekkan tehnik menyusui yang benar.

\section{Cara menyusui yang benar :}

\section{Cara menyusui yang benar}

Adalah cara memberikan ASI kepada bayi dengan perlekatan dan posisi ibu dan bayi dengan benar (Suradi dan Hesti, 2004)

Memberi ASI dalam suasana yang santai bagi ibu dan bayi. Buat kondisi ibu senyaman 
JURNAL ASTA

Abdi Masyarakat Kita

Vol. 02 No. 01, Januari 2022

mungkin. Selama beberapa minggu pertama, bayi perlu diberi ASI setiap 2,5 -3 jam sekali. Menjelang akhir minggu ke enam, sebagian besar kebutuhan bayi akan ASI setiap 4 jam sekali. Jadwal ini baik sampai bayi berumur antara 10-12 bulan. Pada usia ini sebagian besar bayi tidur sepanjang malam sehingga tidak perlu lagi memberi makan di malam hari (Saryono, 2008; h. 30)

\section{Posisi menyusui}

a. Posisi Dekapan

Posisi klasik dan telah menjadi kegemaran kebanyakan para ibu, posisi ini membolehkan

perut bayi dan perut ibu bertemu supaya tidak perlu memutar kepalanya untuk menyusu. Kepala bayi berada di dalam dekapan, sokong kepala badan dan punggung bayi serta lengan bayi perlu berada di bagian sisinya (Saryono,2008; h. 34).

\section{b. Posisi Football hold}

Posisi ini sangat sesuai jika baru pulih dari pembedahan caesar, memiliki payudara yang besar, menyusui bayi prematur atau bayi yang kecil ukurannya atau menyusui anak kembar pada waktu yang bersamaan. Sokong kepala bayi dengan tangan, menggunakan bantal untuk menyokong belakang badan ibu (Saryono, 2008; h; 35).

c. Posisi Berbaring

Posisi ini apabila ibu dan bayi merasa letih. Jika baru pulih dari pembedahan caesar ini mungkin satu-satunya posisi yang biasa dicoba pada beberapa hari pertama. Sokong kepala ibu dengan lengan dan sokong bayi dengan lengan atas (Saryono, 2008; h. 35). 
JURNAL ASTA

Abdi Masyarakat Kita

Vol. 02 No. 01, Januari 2022

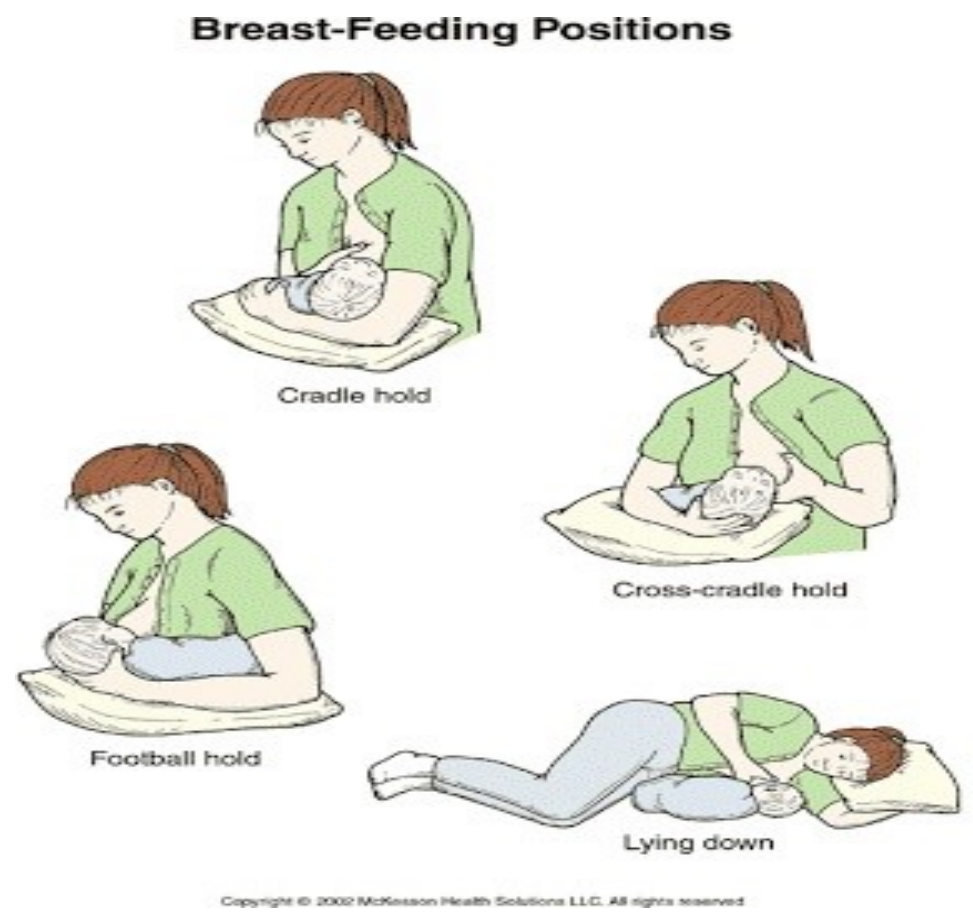

Gambar 2. Jenis-Jenis Posisi Menyusui

\section{Fungsi menyusui yang benar}

1) Puting susu tidak lecet

2) Perlekatan menyusu pada bayi kuat

3) Bayi menjadi tenang

4) Tidak terjadi gumoh

\section{Akibat tidak menyusui dengan benar}

1) Puting susu menjadi lecet

2) ASI tidak keluar secara optimal sehingga mempengaruhi produksi ASI

3) Bayi enggan menyusu

4) Bayi menjadi kembung 


\section{Tanda bayi menyusu dengan benar}

1) Bayi tampak tenang

2) Badan bayi menempel pada perut ibu

3) Mulut bayi terbuka lebar

4) Dagu bayi menempel pada payudara ibu

5) Sebagian areola masuk dalam mulut bayi, areola bawah masuk lebih banyak

6) Bayi Nampak menghisap kuat dengan irama perlahan

7) Puting susu tidak terasa nyeri

8) Telinga dan lengan bayi terletak pada satu garis lurus

9) Kepala bayi agak menengadah

\section{Tanda bayi mendapat ASI dalam jumlah cukup}

1) Bayi akan terlihat puas setelah menyusu

2) Bayi terlihat sehat dan berat badannya naik setelah 2 minggu pertama (100 200grsetiap minggu)

3) Puting dan payudara tidak luka atau nyeri

4) Setelah beberapa hari menyusu, bayi akan buang air kecil 6-8 kali sehari dan buangair besar berwarna kuning 2 kali sehari

5) Apabila selalu tidur dan tidak mau menyusui maka sebaiknya bayi dibangunkan dandirangsang untuk menyusui setiap 2-3 jam sekali setiap harinya.

\section{Langkah-langkah menyusui yang benar}

1) Menjelaskan maksud dan tujuan pendidikan kesehatan

2) Cuci tangan sebelum menyusui dan mengajari ibu

3) Ibu duduk atau berbaring dengan santai (bila duduk lebih baik menggunakan kursi yang rendah agar kaki ibu menggantung dan punggung ibu bersandar pada sandarankursi). 
4) Mempersilahkan dan membantu ibu membuka pakaian bagian atas

5) Sebelum menyusui ASI dikeluarkan sedikit, kemudian dioleskan pada puting dansekitar areola payudara (cara ini mempunyai manfaat sebagai desinfektan dan menjaga kelembaban puting susu).

6) Mengajari ibu untuk meletakkan bayi pada satu lengan, kepala bayi berada padalengkung siku ibu dan bokong bayi berada pada lengan bawah ibu

7) Mengajari ibu untuk menempelkan perut bayi pada perut ibu dengan meletakkan satutangan bayi di belakang badan ibu dan yang satu di depan, kepala bayi menghadap payudara

8) Mengajari ibu untuk memposisikan bayi dengan telinga dan lengan pada garis lurus

9) Mengajari ibu untuk memegang payudara dengan ibu jari diatas dan jari yang lainmenopang dibawah serta jangan menekan puting susu dan areolanya

10) Mengajari ibu untuk merangsang membuka mulut bayi : Menyentuh pipi dengan puting susu atau menyentuh sudut mulut bayi

11) Setelah bayi membuka mulut (anjurkan ibu untuk mendekatkan dengan cepat kepala bayi ke payudara ibu, kemudian memasukkan puting susu serta sebagian besar areola ke mulut bayi)

12) Setelah bayi mulai menghisap, menganjurkan ibu untuk tidak memegang atau menyangga payudara lagi

13) Menganjurkan ibu untuk memperhatikan bayi selama menyusui

14) Mengajari ibu cara melepas isapan bayi (jari kelingking dimasukkan ke mulut bayimelalui sudut mulut atau dagu bayi ditekan ke bawah.

15) Setelah selesai menyusui, mengajarkan ibu untuk mengoleskan sedikit ASI padaputing susu dan areola. Biarkan kering dengan sendirinya

Mengajari ibu untuk menyendawakan bayi : Bayi digendong tegak dengan bersandar pada bahu ibu kemudian punggung ditepuk perlahan-lahan sampai bayi bersendawa (bila tidak bersendawa tunggu 10 - 15 menit) atau bayi ditengkurapkan dipangkuan 
JURNAL ASTA

Abdi Masyarakat Kita

Vol. 02 No. 01, Januari 2022

Peserta sangat antusias mengikuti kegiatan ini karena banyaknya pertanyaan yang mereka ajukan terkait tehnik menyusui, permasalahan asi yang tidak keluar setelah melahirkan, bagaimana penyimpanan dan teknik pemberian ASI Perah (ASIP), Cara mengoptimalkan periode golden Age.

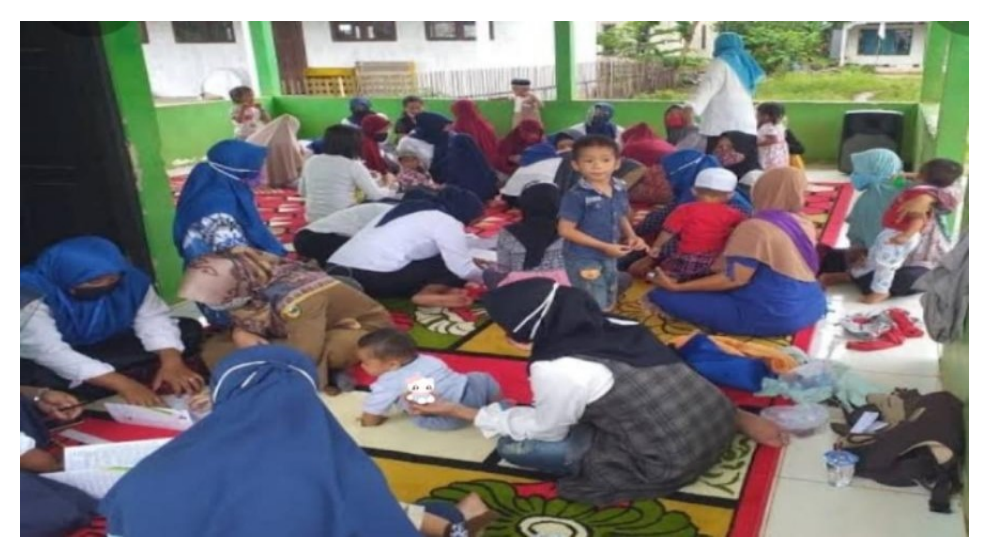

Gambar 3. Peserta antusias mengikuti kegiatan

\section{Kesimpulan}

Kegiatan pengabdian bagi masyarakat di Puskesmas Sukajadi Prabumulih yang dilaksanakan pada tanggal 1 November 2021 hingga 6 November 2021 berjalan dengan lancar dan mendapatkan respon yang baik. Terjadi kesepakatan untuk membuat grup WhatsApp sebagai sarana tanya jawab antara peserta dengan para dosen pelaksana pengabdian masyarakat.

\section{Ucapan Terimakasih}

Ucapan terimakasih kami sampaikan kepada Pimpinan dan Jajaran Staf Puskesmas Sukajadi Prabumulih, Kepala Keluharan Sukajadi, Masyarakat terutama peserta kegiatan, Direktur Akbid Budi Mulia Prabumulih, LPPM Akbid Budi Mulia Prabumulih yang telah memberi dukungan untuk terselenggaranya kegiatan ini.

\section{Daftar Pustaka}

Dewi KF (2016) Efektifitas Pemberian Asi Eksklusif Terhadap Pertumbuhan Dan 135 
JURNAL ASTA

Abdi Masyarakat Kita

Vol. 02 No. 01, Januari 2022

Perkembangan Bayi Di Posyandu Mawar Kecamatan Mersi. Jurnal Kebidanan.7)1):1-13

Hati SF, Lestari P (2016). Pengaruh Pemberian Stimulasi Pada Perkembangan Anak Usia 12 36 Bulan Di Kecamatan Sedayu Bantul Jnki.4(1).

Pusdatin.(2014). Situasi Dan Analisis Asi Eksklusif Jakarta: Kemenkes RI.

Roesli Utami. (2000). Mengenal Asi Eksklusif. Jakarta : Niaga Swadaya.

Satria.(2021).Pentingnya Masa Golden Age Anak.https://ugm.ac.id/id/berita/21802pentingnya-masa-golden-age-anak.

Tetti Seriati Situmorang, Riska Susanti Pasaribu. 2019.Pengaruh Edukasi Berbasis Keluarga Terhadap Pelaksanaan Imd Untuk Pencapaian Asi Eksklusif Untuk Optimalisasi Tumbuh Kembang Anak Pada Periode Emas. Dinamika Kesehatan : Jurnal Kebidanan $\begin{array}{llllll}\text { dan Keperawatan. } & \text { Volume } & 10 & \text { No } & 2 & \text { (2019). }\end{array}$ https://ojs.dinamikakesehatan.unism.ac.id/index.php/dksm/article/view/493Gambar 2. Posisi Menyusui Bayi 